\title{
超高速度撮影による落下雨滴の速度・粒径 および形状の計測 \\ MEASUREMNT OF VELOCITY, DIAMETER AND ASPECT RATIO OF FALLING RAINDROPS BY ULTRA-HIGH-SPEED IMAGING
}

\author{
高野保英1 ・竹原幸生 2 \\ Yasuhide TAKANO and Kohsei TAKEHARA \\ 1正会員 博(工) 近畿大学講師 理工学部社会環境工学科（テ577-8502 東大阪市小若江3-4-1） \\ 2正会員 博(工) 近畿大学教授 理工学部社会環境工学科（†577-8502 東大阪市小若江3-4-1）
}

\begin{abstract}
To measure the falling velocities, the diameters and the aspect ratios of raindrops, consecutive images of raindrops in the open air outside of our laboratory were captured by an ultra-high-speed video camera. For automatic image capturing and avoiding the damage to the image sensor of the video camera due to the strong continuous illumination, a new trigger device was newly introduced to the capturing setup.

As a result of the image analysis of the falling raindrops images, the following findings were obtained, when the equivalent raindrop diameter is smaller than $3 \mathrm{~mm}$. (1)The relationship between the falling velocity and the raindrop diameter determined by our outdoor measurement is similar to that between the terminal velocity and the water drop diameter determined by Gunn and Kinzer's indoor experiment. (2)The aspect ratios of raindrops determined by our measurement is similar to that calculated by Pruppacherr's model of raindrop.
\end{abstract}

Key Words : raindrop, high-speed video camera, drop diameter, terminal velocity

\section{1. はじめに1) 3)}

降水の量的評価あるいは降水発生のメカニズムの理解 を目的として，落下雨滴の粒径分布（単位体積当たりの 雨滴粒子の直径毎の数濃度) の観測が実施されてきた. その代表的な方法は，ウォーターブルーやメチレンブ ルーのような化学物質を吸い込ませた濾紙を用いる方法 である. また，雨滴の代わりとして水滴を落下させ，そ の粒径と落下速度 (終端速度) の関係を求める実験4) 流体力学の理論に基づいた雨滴形状の数值計算) も行わ れた.

さらに，雨滴が振動板に衝突した際の振動や圧力を電 圧に変換して粒径を調べる方法や，雨滴がレーザー光を 通過した際に生じる影から粒径を計測する方法のなど, 粒径分布を電気的に測る機器も開発された. 画像計測の 進歩に伴って雨滴の撮影も試みられ，その例として Muramoto による2台の CCD カメラによる雨滴映像の 撮影》)や，2次元ビデオディスドロメーター ${ }^{8}$ による撮影 が挙げられる. Testik らは，アメリカで発生した実際の 降雨の落下雨滴をストロボ撮影し，その連続写真から落
下中の雨滴が周期的な変形を繰り返していることを示し た9).さらに，小型ビデオカメラを搭載したビデオゾン デや雲粒子ゾンデ（HYVIS）を用いて，雲粒子や降水粒 子の径・形状・個数などの空間分布の計測も盛んに行わ れている10),11).

しかしながら，これらの撮影例の多くは静止画像の撮 影であり，超高速の動画像または非常に短い時間間隔で の静止画像の撮影の例は見られない. 低速の動画像や静 止画像でも, 粒径分布や落下速度の計測であれば十分で はあるが，雨滴生成・成長のメカニズムの理解に必要と なる, 落下中の雨滴の変形や衝突・分裂などの動的な挙 動の把握は困難である. またその撮影に当たって, 鉛直 風洞を用いた例もあるが，これは自然状態で落下寸る雨 滴ではないと判断される.

筆者らは，最大 100 万枚/秒で撮影可能なビデオカ

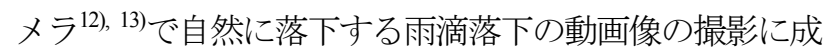
功し, 目視およびデジタル画像処理により雨滴粒径およ び落下速度の計測を試みている14)。これまでの撮影およ び計測から，以下のような結果を得た。

(1) 自然落下の雨滴の速度と粒径の関係は, Gunn と Kinzer が実験的に求めた落下水滴の粒径と終端速度 
の関係と良く一致した。

(2) 画像中の雨滴の形状を棈円の方程式で近似させ，鉛 直方向および水平方向の径を調べた結果，自然落下 の雨滴は横長の形状であることが確認された.

ただし上記の撮影ではデータ数が限られていたことに 加え, 解析対象が相当直径（雨滴を真球とみなした場合 の直径） $1.5 \mathrm{~mm}$ 程度までの雨滴がほとんどであったた め，撮影例を増やし，粒径と落下速度の関係について更 なる検討を加えるという課題が残った.

その後, 雨滴撮影の照明システムに改良を加え, 撮影 を実施した結果，相当直径 $3 \mathrm{~mm}$ 程度までの雨滴の撮影 に成功し, 粒径と落下速度の関係および雨滴の形状に関 する知見が得られた. 特に, 約 $3 \mathrm{~mm}$ までの雨滴の鉛直 方向の径と水平方向の径の関係について，理論に基づい た雨滴形状の数値計算結果との比較が可能になったので, ここに紹介する.

\section{2. 撮影方法}

\section{（1）撮影装置の概要}

落下雨滴撮影装置の概要を図-1に示す。

撮影装置は, 超高速ビデオカメラ, 撮影卜リガー, LED トリガーおよび LED 照明から成る. 超高速ビデ オカメラの撮影制御（撮影停止と画像保存の制御）のた めの撮影卜リガーは，鉛直方向には撮影領域の直下，光 軸方向にはレンズ先端から約 $20 \mathrm{~cm}$ 離れた位置に設置 される. また LED トリガーは，レーザーダイオードと フォトダイオードから成り, 撮影トリガー上方に設置さ れ，LED 照明は撮影領域背後に設置される.

雨滴が LED トリガーを横切り, 撮影トリガー上に落 下した時にのみ，LED 照明が点灯し，ビデオカメラは 動画を記録・保存する（トリガーについては後述）。

なお，事前にトリガーと同じ地点に針を設置し，少し ずつ移動させながら静止画像を撮影し，それらの画像を 基に撮影領域の大きさを計測した.

\section{（2）超高速ビデオカメラ ${ }^{12), 13)}$}

超高速ビデオカメラは筆者らが開発したものであり， 斜行直線 CCD 型画素周辺記録型撮像素子 (ISIS) によ り, 最高 100 万枚 $/$ 秒で $81,120(312 \times 260)$ 画素の画 像を, 103 枚連続して撮影することが可能である. ただ し撮影枚数には制限があり, 撮影可能な時間には限りが ある(例えば 1 万枚/秒の撮影の場合, 約 1/100 秒間 のみ撮影可能) ため, カメラのセンサーには連続上書き 機能を搭載し，また撮影卜リガー用いることにより，所 望の現象の撮影を可能にしている. すなわち動画の撮影 は撮影終了まで連続的に続けられ，メモリ上の画像は上 書きされ続ける. 所望の現象が生じた直後にトリガーを 通じて撮影を終了させ，最新の 103 枚の画像（BMP 形

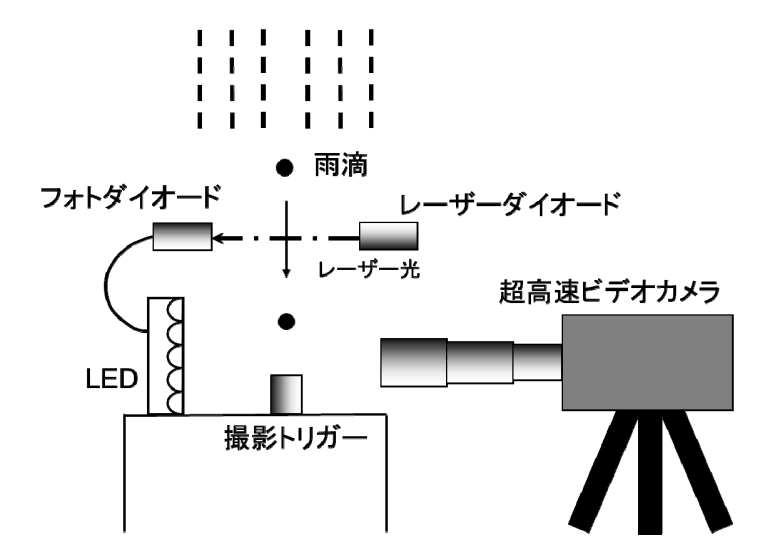

図-1＼cjkstart撮影装置の概略

表-1 撮影条件の概要

\begin{tabular}{|c|c|c|c|}
\hline 撮影日時 & 撮影速度 & 撮影領域 & 降水量 \\
\hline $\begin{array}{l}2013 / 7 / 14 \\
15: 00 \sim 16: 00\end{array}$ & 1 万枚 /秒 & $30.29 \times 25.24 \mathrm{~mm}$ & $0.5 \mathrm{~mm}(16: 00)$ \\
\hline $\begin{array}{l}2013 / 7 / 29 \\
13: 30 \sim 15: 00\end{array}$ & $\begin{array}{l}\text { 1万または } \\
\text { 2万枚 /秒 }\end{array}$ & $23.86 \times 19.88 \mathrm{~mm}$ & $\begin{array}{l}5.5 \mathrm{~mm}(14: 00) \\
0.5 \mathrm{~mm}(15: 00)\end{array}$ \\
\hline $\begin{array}{l}2013 / 10 / 09 \\
10: 30 \sim 13: 00\end{array}$ & 2万枚 $/$ 秒 & $39.58 \times 32.99 \mathrm{~mm}$ & $\begin{array}{l}4.5 \mathrm{~mm}(11: 00) \\
7.0 \mathrm{~mm}(12: 00) \\
6.0 \mathrm{~mm}(13: 00)\end{array}$ \\
\hline
\end{tabular}

式）を保存し，動画（AVI 形式）を作製する.

雨滴の撮影に当たっては，このビデオカメラに焦点距 離 80 〜 200mm の望遠レンズと接写リングを取り付け る.

\section{(3) 撮影トリガー}

撮影トリガーは, 市販のイヤフォンのカバー部を取り 外して, 内部の振動膜を露出させ，塩ビパイプ内に固定 したものである. 振動膜に雨滴が衝突した際に生じる電 圧を，オペアンプで増幅し，その増幅された電圧が一定 の值を超えた場合に, ビデオカメラの撮影が終了寸る. 振動膜自体の直径は $1.2 \mathrm{~cm}$ であり, どの部分に雨滴が 落下しても信号が発生する.

ただし雨滴の撮影に当たっては, 望遠レンズおよびリ ングを用いて接写・拡大しているため, 焦点深度が非常 に浅くなる．その結果，焦点から外れた位置に雨滴が落 下し，明瞭に撮影されない場合がある，そのため，振動 膜の上に直径 $3 \mathrm{~mm}$ の穴を開けたプラスチック板を載せ ることで，トリガーが動作する位置を絞り，その位置に 焦点を合わせた.

\section{（4）LED照明}

撮影領域背後にトレーシングペーパーを貼り付けた透 明板を置き，さらにその背後に LED 照明を設置する. また以下の理由により, 撮影卜リガー上方に設置した LED トリガーにより, LED の点滅を制御する.

筆者らはこれまでに，(1) 撮影領域背後に設置した白 色版に照明を向けその反射光を撮影領域に照射する，(2) 撮影領域背後にトレーシングペーパーを貼り付けた透明 板を置き，その背後から照明を照射する，の二通りの照 


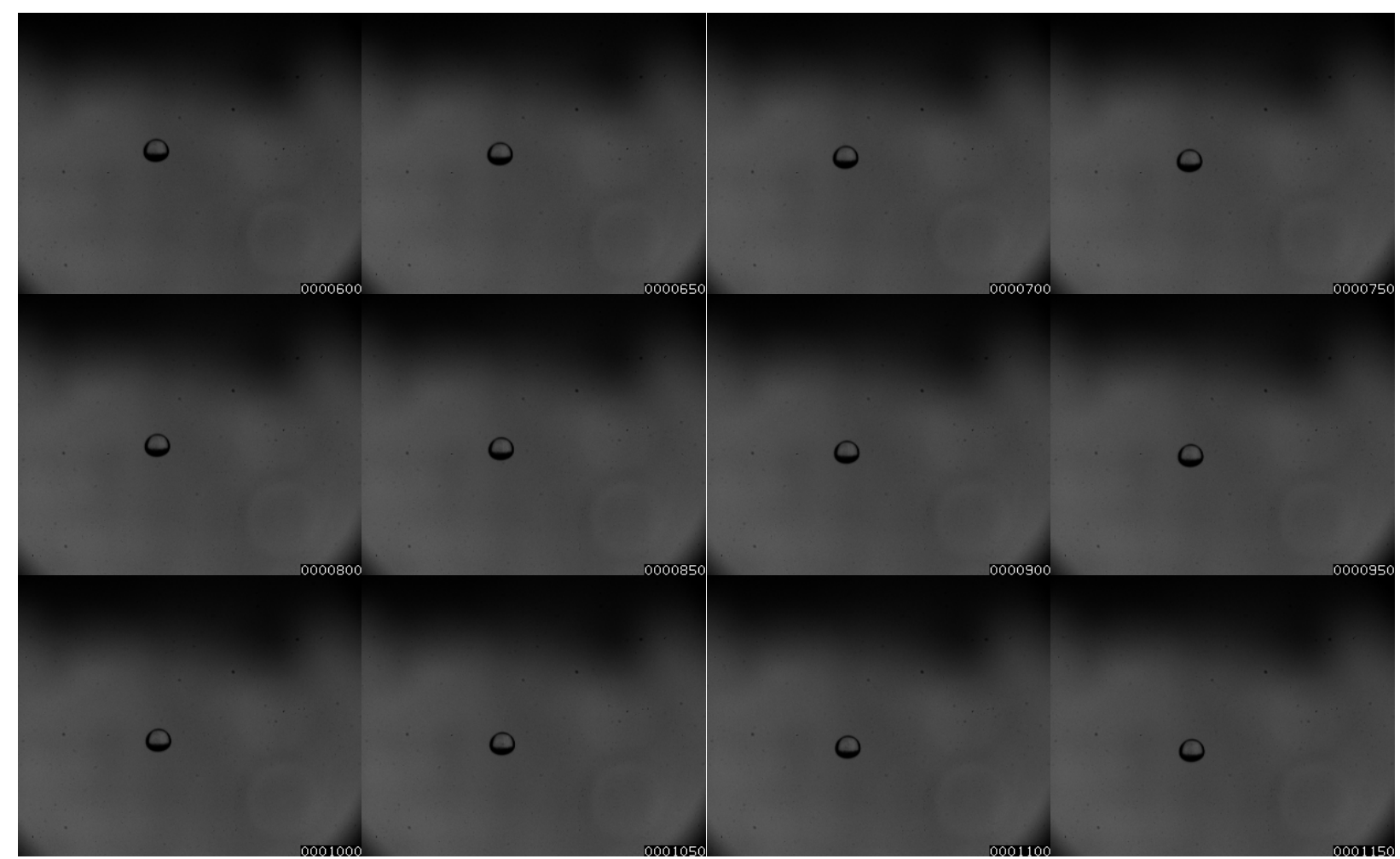

写真-1 落下雨滴の画像例（撮影速度20,000枚/秒，相当直径 $3.033 \mathrm{~mm}$ )

明方法で雨滴の撮影を行った. 直径 $3 \mathrm{~mm}$ の撮影卜リ ガー上に雨滴が落下寸る確率はかなり低く，予測不可能 であるため，これらの照明方法では，撮影が完了寸るま で照明を照射し続けることになる．しかし，強い照明に よりカメラの素子の劣化が激しくなるため, 撮影の際に 長時間に亘って照明をカメラに向けることは, 望ましく ない，そこで，レーザーポインターとフォトダイオード から成る LED トリガーを作製し，雨滴が撮影領域を落 下寸る場合のみ, LED 照明が点灯するようにした.

レーザーポインターとフォトダイオードを, 約 $20 \mathrm{~cm}$ 間隔で正対して撮影領域上部に設置し，レーザー光を フォトダイオードに照射する．この際，レーザー光が撮 影トリガーの真上を通過するように，レーザーポイン ターとフォトダイオードの位置を調整する. フォトダイ オードは, 制御回路を通じて LED 照明に接続されてい る. 上方から落下した雨滴がレーザー光を横切って通過 し，フォトダイオードに入射するレーザーの光量がある 程度低下した時のみ, LED が点灯する（約 3 秒後に自 動的に消灯）。その後，レーザー光を横切った雨滴が， 撮影トリガーに落下すると撮影が完了する.

\section{3. 撮影結果および雨滴の落下速度と形状の計測}

\section{（1）撮影条件}

撮影場所は近畿大学理工学部水工学実験室前 (大阪府 八尾市），撮影日時は 2010 年 7 月 14 日 15:00
16:00， 7 月 29 日 13:30 15:00, および 10 月 9 日 10:30 13:00 である. 参考として，これらの時間 帯の大阪管区気象台発表の大阪の降水量を, 表-1に示寸. 同表には，撮影時の撮影速度および撮影領域も示す.

これらの 3 回の撮影で，合わせて 21 例の落下雨滴 の撮影に成功した.

\section{（2）撮影画像}

落下雨滴の連続画像の例を写真-1に示寸，撮影速度は 2 万枚/秒であり, 画像の時間間隔は $0.05 \mathrm{~ms}$ となる.

雨滴は, 端部がやや黒っぽい透明の球体として画像に 記録されており, 雨滴の輪郭は, 後述する粒径の解析が 可能な程度に明瞭に示されている.

\section{（3）落下雨滴の終端速度と粒径の関係}

静止流体中を落下寸る粒子は，流体抵抗を受けて最終 的に重力と抵抗力が平衡した状態で落下寸る. このとき の落下速度を, 終端速度（Terminal velocity）という。落 下中の雨滴も同様に，落下中のある時点で終端速度に達 し，その速度を維持しながら落下を続けると考えられる。 Gunn とKinzer ${ }^{4)}$ は, 粒径毎の水滴の終端速度を実験的 に求めた．この結果を基にした落下速度を表す式も，幾 つか提案されている。 なお，落下中の水滴の形状は必ず しも真球ではなく，形状に関する理論に基づく計算にお いても，水滴が大きくなるにつれて扁平になるとされて いる. ここで示される粒径は，体積を基に水滴を真球と みなした場合の直径に換算したもの（相当直径あるいは 


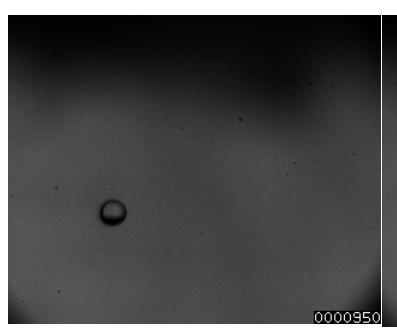

(a) 撮影画像

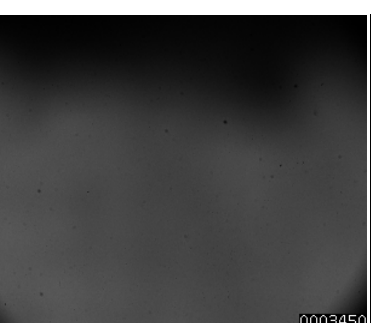

(b) 背景画像

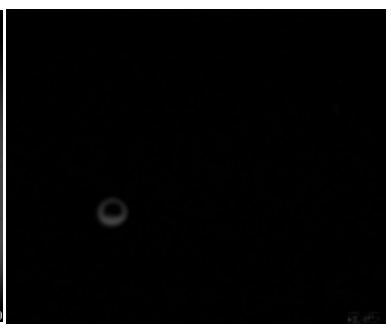

（c）撮影画像から背景画像 を差し引いた画像

\section{0}

(d) 雨滴端部の抽出

図-2 画像処理による雨滴形状の計測

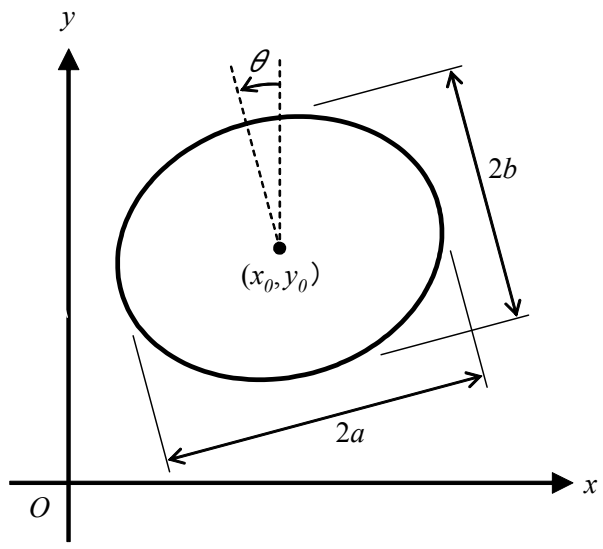

図-3 雨滴形状の算出に用いる楕円方程式

\section{（4）撮影画像からの雨滴落下速度と粒径の計測 ${ }^{14)}$}

コンピュータによる画像処理により，以下の手順で撮 影画像から雨滴の落下速度および粒径を求めた（図-2参 照).

なお撮影された雨滴は総て，Gunn と Kinzer の実験 とは異なり，鉛直軸方向のみならず水平軸方向への移動 も生じており，雨滴の落下速度べクトルは鉛直軸に対し て若干の角度を有する. またカメラ一台の撮影であるた め, 落下ベクトルの光軸方向の傾きは検出し難い. ここ では，鉛直成分および水平成分の合力として落下速度を 求めた。

(1) 撮影した連続画像のうち, 雨滴が写っていない連続 10枚の画像から，背景画像を作成する（図-2(b)）。

(2) 雨滴が写っている画像すべてについて, 平滑化の処 理を加え, 背景画像の輝度值を差し引いた画像を作 成する. この処理の結果として，雨滴の部分が白い 画像が作成される（図-2(c)）。

(3) 上記の差し引き画像中で, 輝度值の変化が大きい画 素を抽出し，その周囲の画素の輝度值を基に密度重 心を求め, 最も輝度值の変化が大きい画素の位置 （サブピクセル）を算出する。この位置の集合体を， 雨滴の輪郭とする（図-2(d)）。

(4) (3) の雨滴の輪郭のプロットデータに, パウエル法を 用いて以下の楕円の方程式を適合させ，雨滴の中心 座標, 水平 $(x$ 軸) 方向および鉛直 $(y$ 軸) 方向の

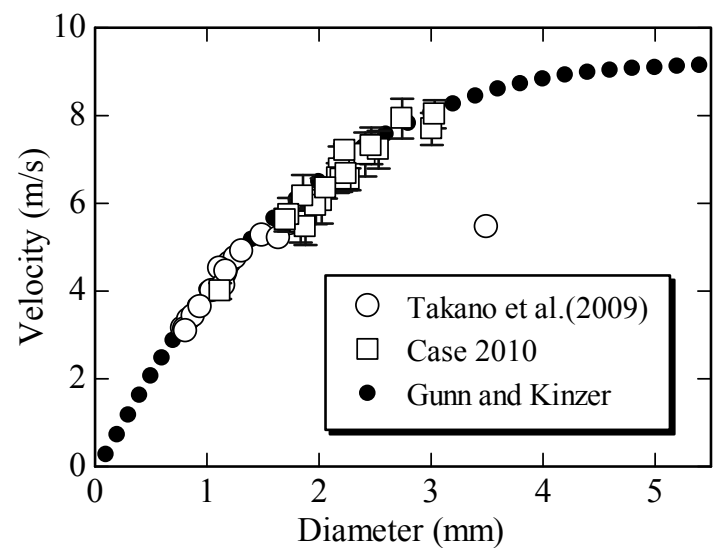

図-4＼cjkstart雨滴粒径と落下速度の関係

径を算出する（図-3参照）.

$$
\begin{aligned}
\frac{\left\{\left(x-x_{0}\right) \cos \theta+\left(y-y_{0}\right) \sin \theta\right\}^{2}}{a^{2}} & \\
+\frac{\left\{-\left(x-x_{0}\right) \sin \theta+\left(y-y_{0}\right) \cos \theta\right\}^{2}}{b^{2}} & =1
\end{aligned}
$$

ここに， $x_{0}$ : 楕円中心の $x$ 座標， $y_{0}$ : 楕円中心の $y$ 座標, $a: x$ 軸方向の楕円の半径, $b: y$ 軸方向の楕 円の半径， $\theta: x$ 軸および $y$ 軸に対する楕円の傾き (反時計回り正)，である.

(5) 式(1)より得られた雨滴の中心の移動量から, 落下速 度を算出する. また，水平方向および鉛直方向の径 を用いて雨滴の体積を求め, 雨滴を真球としたとき の相当直径（粒径）を算出する. 落下速度および相 当直径とも，雨滴が映っている画像総てについて求 め, 平均值を採用する.

\section{（5）落下速度および粒径の計測結果}

撮影画像から求めた雨滴落下速度と相当直径の関係を, 図-4に示す（口）。同図には，落下速度の標準偏差（エ ラーバー），筆者らが以前の撮影 ${ }^{12)}$ で求めた落下速度と 相当直径の関係 (○)，および Gunn と Kinzer ${ }^{4)}$ が実 験的に求めた落下水滴と終端速度の関係（○）も示す.

筆者らは, 2006 年の撮影および解析の結果, $1.5 \mathrm{~mm}$ 程度までの雨滴の落下速度と相当直径の関係は，Gunn と Kinzer が求めた結果と良く一致していること，およ 
表-2 雨滴の水平方向の径, 鉛直方向の径および相当直径の平均值, 標準偏差, 最大值および最小值

\begin{tabular}{|c|c|c|c|c|c|c|c|c|c|c|}
\hline \multirow[b]{2}{*}{ 番号 } & \multirow[b]{2}{*}{ 画像数 } & \multicolumn{3}{|c|}{ 水平方向の径(mm) } & \multicolumn{3}{|c|}{ 鉛直方向の径 $(\mathrm{mm})$} & \multicolumn{3}{|c|}{ 相当直径 (mm) } \\
\hline & & 平均値 & 標準偏差 & $\begin{array}{c}\text { 最大値 } \\
\text { 最小値 }\end{array}$ & 平均値 & 標準偏差 & $\begin{array}{c}\text { 最大値 } \\
\text { 最小値 }\end{array}$ & 平均值 & 標準偏差 & $\begin{array}{l}\text { 最大値 } \\
\text { 最小値 }\end{array}$ \\
\hline \multirow{2}{*}{ CASE-a } & \multirow{2}{*}{27} & \multirow{2}{*}{2.369} & \multirow{2}{*}{0.0193} & 2.400 & \multirow{2}{*}{2.090} & \multirow{2}{*}{0.0243} & 2.133 & \multirow{2}{*}{2.272} & \multirow{2}{*}{0.0123} & 2.291 \\
\hline & & & & 2.307 & & & 2.041 & & & 2.244 \\
\hline \multirow{2}{*}{ CASE-b } & \multirow{2}{*}{6} & \multirow{2}{*}{2.250} & \multirow{2}{*}{0.0611} & 2.314 & \multirow{2}{*}{2.060} & \multirow{2}{*}{0.0634} & 2.143 & \multirow{2}{*}{2.184} & \multirow{2}{*}{0.0190} & 2.204 \\
\hline & & & & 2.158 & & & 1.995 & & & 2.153 \\
\hline \multirow{2}{*}{ CASE-c } & \multirow{2}{*}{33} & 2872 & 00249 & 2.946 & 2498 & 00364 & 2.563 & 2741 & 00175 & 2.799 \\
\hline & & 2.016 & 0.0245 & 2.824 & 2.450 & 0.0504 & 2.429 & 2.141 & 0.0170 & 2.699 \\
\hline CASE-d & 20 & 2079 & 00531 & 2.156 & 1917 & 00656 & 2.001 & 2023 & 00293 & 2.076 \\
\hline UASE- $-\mathrm{a}$ & 20 & 2.019 & 0.0501 & 1.962 & 1.911 & 0.0000 & 1.705 & $2.0<0$ & 0.0290 & 1.968 \\
\hline CASE-e & 30 & 2491 & 00263 & 2.553 & 2264 & 00408 & 2.370 & 2413 & 00219 & 2.490 \\
\hline CASE-e & 30 & 2.491 & 0.0203 & 2.445 & 2.204 & 0.0408 & 2.178 & 2.413 & 0.0219 & 2.383 \\
\hline CASE-f & 14 & 1882 & 00531 & 1.954 & 1750 & 00550 & 1.851 & 1836 & 00241 & 1.876 \\
\hline CASE- -1 & 14 & 1.882 & 0.0531 & 1.770 & 1.150 & 0.0550 & 1.662 & 1.836 & 0.0241 & 1.792 \\
\hline CASF- $\sigma$ & 26 & 2238 & 00344 & 2.306 & 2033 & 00413 & 2.209 & 2167 & 00160 & 2.201 \\
\hline UASE- & & & & 2.112 & & & 1.964 & & 0.0100 & 2.135 \\
\hline CASE-h & 31 & 2636 & 00419 & 2.755 & 2338 & 00421 & 2.448 & 2532 & 00274 & 2.597 \\
\hline UASE-n & 31 & 2.030 & 0.04119 & 2.591 & 2.338 & $0.04 \angle 1$ & 2.267 & 2.032 & 0.0214 & 2.483 \\
\hline CASE-i & 33 & 2568 & 00269 & 2.614 & 2276 & 00421 & 2.346 & 2466 & 00163 & 2.498 \\
\hline UAOE-T & 00 & 2.000 & 0.0200 & 2.509 & 2.270 & $0.04<1$ & 2.136 & 2.400 & 0.0100 & 2.434 \\
\hline CASE-i & 34 & 3133 & 00739 & 3.343 & 2771 & 00367 & 2.842 & 3007 & 00381 & 3.126 \\
\hline UASE-J & 34 & 3.135 & 0.0739 & 3.063 & 2.171 & 0.0301 & 2.667 & 3.007 & 0.0381 & 2.968 \\
\hline CASF-k & 20 & 2040 & 00291 & 2.089 & 1844 & 0.0348 & 1.950 & 1972 & 00182 & 2.006 \\
\hline & & & & 1.969 & & & 1.774 & & & 1.940 \\
\hline CASF-I & 25 & 2269 & 00479 & 2.336 & 2063 & 00452 & 2.202 & 2198 & 00243 & 2.242 \\
\hline$U A O E^{-1}$ & & & & 2.128 & & & 1.993 & & & 2.139 \\
\hline CASE-m & 38 & 3166 & 00256 & 3.241 & 2783 & 0.0328 & 2.851 & 3033 & 0.0157 & 3.064 \\
\hline UASE-m & 38 & 3.100 & $0.0<50$ & 3.110 & 2.183 & $0.03<8$ & 2.705 & & 0.0151 & 3.000 \\
\hline CASE- $n$ & 14 & 1954 & 0.0214 & 1.998 & 1737 & & 1.798 & 1879 & & 1.917 \\
\hline & & & 0.0214 & 1.921 & 1.131 & $0.0<43$ & 1.694 & $1.8 / 9$ & 0.0108 & 1.854 \\
\hline
\end{tabular}

$\bigcirc$ Takano et al.(2009) $\square$ Case 2010
$\triangle$ Pruppacher and Pitter

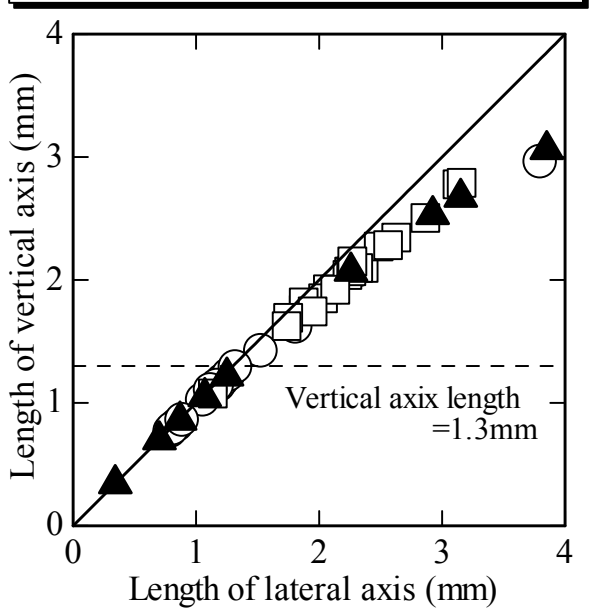

図-5＼cjkstart雨滴の水平方向の径および鉛直方向の径の関係

び約 $1.5 \mathrm{~mm}$ から, 直径が大きくなるに従って両者のず れが大きくなることを指摘した ${ }^{14)}$. 今回の撮影および解 析の結果，相当直径が $1.5 \sim 3 \mathrm{~mm}$ 程度の範囲におい ても，画像から求めた雨滴の落下速度と相当直径の関係 は, Gunn と Kinzer の結果と良く一致していることが 分かる。

\section{（6）落下雨滴の形状の測定}

表-2に，10月 9 日に撮影された雨滴について水平方 向の径，鉛直方向の径および相当直径の平均值，標準偏 差，最大值および最小值を示す.

この表より，相当直径が $1.5 \sim 3 \mathrm{~mm}$ 程度の範囲に おいても，雨滴の水平方向の径の方は，鉛直方向のそれ よりも若干大きいこと，すなわち雨滴はやや横長の形状 であることが分かる，なお，水平方向および鉛直方向の 径の標準偏差は $0.02 \sim 0.09 \mathrm{~mm}$ 程度，また最大值と最 小值の差は $0.1 \sim 0.3 \mathrm{~mm}$ 程度，画素にして $1 \sim 2.5$

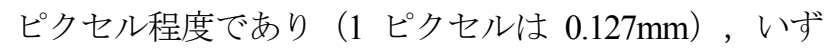
れも小さい.

図-5に，雨滴の鉛直方向の径と水平方向の径の関係を 示す $(\square)$. 同図には，筆者らが以前の撮影(14)で求めた 結果（○），および Pruppacherr ら5)が流体力学の理論 に基づいて求めた雨滴形状から得られた鉛直方向の径と 水平方向の径の関係 $(\boldsymbol{\Delta})$ も示す.

Pruppacherr らは, 雨滴形状の物理モデルを提案し, 雨滴の形状を示す以下の式を提案した。

$$
r=a_{0}\left(1+\sum_{n=0}^{\infty} c_{n} \cos n \theta\right)
$$


ここに, $r$ : 雨滴の半径, $a_{0}$ : 雨滴の相当半径, $c_{n}$ : 変形 係数， $\theta$ : 雨滴の鉛直軸と雨滴表面がな寸角，である.

Pruppacherr らは, $a_{0}=0.01711 \sim 0.40 \mathrm{~cm}$ までの 15 個の雨滴の変形係数を, $n=0 \sim 9$ までについて求めて いる. 今回の撮影で, 相当直径 $1 \mathrm{~mm}$ 弱から $3 \mathrm{~mm}$ 程 度までの自然に落下寸る雨滴のデータが揃ったため, 比 較・検討の目的で, Pruppacherr らが示したモデルと数 值に基づいて雨滴の形状を求め, 鉛直方向および水平方 向で最も大きい径の関係を図-5に示した.

鈆直方向の径が $1.3 \mathrm{~mm}$ (同図中，破線で示す）より も大きい場合, 径が大きくなるにつれて, 各点の $1: 1$ の直線からの下方へのずれが大きくなり, 雨滴の扁平率 が増すことが分かる．また少なくとも，鉛直方向の径と 水平方向の径の関係については, 撮影画像から求めた結 果は, Pruppacherr らが求めた結果と良好に一致するこ とが分かった。

今後はさらに雨滴を拡大した撮影例を増やし，撮影画 像から求めた落下雨滴の形状と Pruppacherr らのモデル から得られる形状との比較や変形係数の同定などにより， モデルの検討・改良を試みる必要があると考える.

\section{4. 結論}

100 万枚/秒で 103 枚の連続画像が撮影可能な超高 速ビデオカメラを用いて，自然状態で落下寸る雨滴の粒 径，速度，動的挙動などの動画像による計測を試みてい る.

これまでの撮影方法を改良し，撮影例を蓄積した結果， 自然に落下寸る雨滴の粒径と落下速度の関係，および落 下雨滴の形状に関してさらにデータが加わり, これまで に求められた粒径と落下速度の実験結果や雨滴形状の解 析結果との比較から，以下のような知見が得られた.

(1) 今回の撮影で相当直径 $1.5 \sim 3 \mathrm{~mm}$ 程度の雨滴の 落下速度と粒径の関係が得られたが，この関係は Gunn と Kinzer が実験的に求めた落下水滴の粒径 と落下速度の関係と良く一致した，従って，既往の 撮影・解析結果を含めると, 相当直径 $3 \mathrm{~mm}$ 程度ま では, Gunn と Kinzer の実験結果と良好に一致す ることが確認された。

(2) 撮影で得られた画像中の雨滴の形状を楕円の方程式 で近似させ，鉛直方向および水平方向の径を調べた その結果, 相当直径 $3 \mathrm{~mm}$ 程度まででは, 雨滴の鉛 直方向と水平方向の径の比については，Pruppacherr らが提案した雨滴の形状の物理モデルにより得られ る結果と良好に一致した。

今後はさらに雨滴の撮影例の蓄積に努めるともに，雨 滴形状を高精度に検出するために拡大撮影を試み, Pruppacherr らが提案した落下雨滴の形状の物理モデル と実際の落下雨滴の形状の比較, および変形係数の同定
などによる Pruppacherr らのモデルの検討・改良が課題 として挙げられる.

\section{参考文献}

1) 水野量 : 雲と雨の気像学, pp. 58-67, 朝倉書店, 2000.

2) 吉野文雄 : レーダ水文学, pp. 65-70, 森北出版, 2002.

3) 武田喬生 : 雨の科学, pp. 1-23, 成山堂, 2005 .

4) Gunn, R. and Kinzer, K. D.: The Terminal Velocity of Fall for Water Droplets in Stagnant Air, Journal of Meteorology, Vol. 6, pp. 243-248, 1949.

5) Pruppacher, H. R. and Pitter, R.L.: A Semi-Empirical Determination of the Shape of Cloud and Rain Drops, Journal of Atmospheric Sciences, Vol. 28, pp. 86-94, 1971.

6) 山田正, 日比野忠史, 鈴木敦, 峦島弥成, 中津川誠 : 新しい タイプのレーザー雨滴計の開発とこれを用いた降雨の雨滴粒 径分布の観測，土木学会論文集，No. 539／II-35, pp. 15-30, 1996.

7) Muramoto, K. : Determination of Shape and Fall Velocity of Raindrops by Image Processing, IECE Trans. Inf. and Syst., Vol. E78-D, No. 8, pp. 1051-1057, 1995.

8) Kruger, A. and Krajewski, W. F. : Two-Dimensional Video Disdrometer: A Description, Journal of Atmospheric and Oceanic Technology, Vol. 19, No. 5, pp. 602-617, 2002.

9) Testik, F. Y., Barros, A. P. and Bliven, L. F. : Field Observations of Multimode Raindrop Oscillations by High-Speed Imaging, Journal of the Atmospheric Sciences, Vol. 63, pp. 2663-2668, 2006.

10) Suzuki, K., Shigenaga, Y., Kawano, T. and Yoneyama, K. : Videosonde Observations during the R/V Mirai MR04-08 Cruise, 海と空, Vol.82, No. 2, pp. 1-10, 2006.

11) Orikasa, N., Nagai, T., Murakami, M, Kusunoki, K., Mori, K., Hashimoto, A., Mastumura, T. and Shibata, T. : Optical and Microphysical Properties of Upper Clouds Measured with the Raman Lidar and Hydrometeor Videosonde: A Case Study on 29 March 2004 over Tsukuba, Japan, Journal of the Atmospheric Sciences, Vol. 63, pp. 2156-2166, 2006.

12) Etoh, T. G., Poggemann, D., Kreider, G., Mutoh, H., Theuwissen, A. J. P., Ruckelshausen, A., Kondo, Y., Maruno, K., Takubo, K., Soya, H., Takehara, K., Okinaka, T. and Takano, Y. : An Image Sensor which Captures 100 Consecutive Frames at 1,000,000 Frames/s, IEEE Transactions on Electron Devices, Vol. 50, No. 1, pp. 144-151, 2003.

13) Ohtake, H., Hayashida, T., Kitamura, K., Arai, T., Yonai, J., Tanioka, K., Maruyama, H. and Etoh, T. : 300,000-pixel Ultrahighspeed High-sensitivity CCD and a single-chip Color Camera Mounting This CCD, Broadcast Technology, No. 28, pp. 2-9, 2006.

14) 高野保英, 竹原幸生, 江藤岡治 : 雨滴の超高速動画撮影に よる落下速度・形状の計測，土木学会論文集B，Vol. 65 , No.4, pp. 332-340, 2009.

（2013. 9. 30受付） 